Article

\title{
Irrigation with Activated Water Promotes Root Growth and Improves Water Use of Winter Wheat
}

\author{
Guoqing Zhao ${ }^{1,2}$, Beibei Zhou ${ }^{2}$, Yan Mu ${ }^{3, *}$, Yanhui Wang ${ }^{1}$, Yuqi Liu ${ }^{1}$ and Li Wang ${ }^{1}$ \\ 1 College of Natural Resources and Environment, Northwest A\&F University, Xianyang 712100, China; \\ zhaogq007@126.com (G.Z.); 18235701870@163.com (Y.W.); mysterysummer2@163.com (Y.L.); \\ wangli5208@163.com (L.W.) \\ 2 State Key Laboratory of Eco-Hydraulics in Northwest Arid Region, Xi'an University of Technology, \\ Xi'an 710048, China; happyangle222@aliyun.com \\ 3 College of Landscape Architecture and Art, Northwest A\&F University, Xianyang 712100, China \\ * Correspondence: muyan@nwafu.edu.cn
}

Citation: Zhao, G.; Zhou, B.; Mu, Y.; Wang, Y.; Liu, Y.; Wang, L. Irrigation with Activated Water Promotes Root Growth and Improves Water Use of Winter Wheat. Agronomy 2021, 11, 2459. https://doi.org/10.3390/ agronomy11122459

Academic Editor: Alberto San Bautista

Received: 18 October 2021 Accepted: 30 November 2021 Published: 2 December 2021

Publisher's Note: MDPI stays neutral with regard to jurisdictional claims in published maps and institutional affiliations.

Copyright: ( $\odot 2021$ by the authors Licensee MDPI, Basel, Switzerland. This article is an open access article distributed under the terms and conditions of the Creative Commons Attribution (CC BY) license (https:// creativecommons.org/licenses/by/ $4.0 /)$.

\begin{abstract}
Magnetic or oxidation treatment of irrigation water can promote the transport of water and nutrients by the root system, improve the efficiency of water and fertilizer use and potentially increase yields. Hydroponic and field experiments were conducted to explore how irrigation with magnetized and/or oxidized water affects grain yield and water-use efficiency (WUE) in winter wheat with an emphasis on physiological changes in the root system. Hydroponic cultivation of winter wheat with pure groundwater and brackish water included the following treatments: control group $(\mathrm{CK}-\mathrm{G}$, $\mathrm{CK}-\mathrm{B})$; magnetization $(\mathrm{GM}, \mathrm{BM})$; oxidation $(\mathrm{GO}, \mathrm{BO})$; and the combination of magnetization and oxidation $(\mathrm{G}(\mathrm{M}+\mathrm{O}), \mathrm{B}(\mathrm{M}+\mathrm{O}), \mathrm{G}(\mathrm{O}+\mathrm{M}), \mathrm{B}(\mathrm{O}+\mathrm{M}))$. Field experiments only tested irrigation with various types of groundwater, including the control group (IG), magnetization treatment (IGM), oxidation treatment (IGO), and the combination of the two treatment methods ( $\mathrm{GG}(\mathrm{M}+\mathrm{O}), \mathrm{IG}(\mathrm{O}+\mathrm{M})$ ). Hydroponic cultivation revealed that the magnetic treatment and oxidation of both groundwater and brackish water can significantly improve the root vigor of winter wheat, i.e., improvements of $100.5-253.7 \%$ and $100.4-213.9 \%$ were seen in the groundwater and brackish treatment groups, respectively, relative to the control group. The root length density (RLD) of wheat increased by $67.6 \%$ (GM), $79.4 \%$ (GO), $7.5 \%(\mathrm{BM})$, and $40.0 \%$ (BO) relative to the respective control groups (CK-G and $\mathrm{CK}-\mathrm{B})$. Moreover, the root weight density (RWD) for $\mathrm{BO}$ and $\mathrm{B}(\mathrm{O}+\mathrm{M})$ treatments improved significantly ( $66.7 \%$ and $55.4 \%$, respectively) relative to $\mathrm{CK}-\mathrm{B}$. The maximal increases in root surface area density (RSD) were observed in treatments $\mathrm{GO}$ and $\mathrm{B}(\mathrm{O}+\mathrm{M})$, which showed values $125 \%$ and $100 \%$, respectively, higher than what was measured for the control groups. The root/shoot ratios of the $\mathrm{GO}$ and $\mathrm{G}(\mathrm{O}+\mathrm{M})$ treatments improved significantly (by $75.3 \%$ and $62.0 \%$, respectively) relative to $\mathrm{CK}-\mathrm{G}$. The results of field experiments showed that wheat in the IGO and $\mathrm{GG}(\mathrm{O}+\mathrm{M})$ plots absorbed more water from the soil than wheat in the of IG plots (increases of $13.9 \%$ and $16.9 \%$, respectively). Furthermore, the IGO and $\mathrm{IG}(\mathrm{O}+\mathrm{M})$ treatments produced significantly higher grain yields and WUE than the IG plots, with IGO producing the maximum yield $\left(11.7 \times 10^{3} \mathrm{~kg} \mathrm{ha}^{-1}\right)$ and $\mathrm{IG}(\mathrm{O}+\mathrm{M})$ the highest observed WUE $\left(30.3 \mathrm{~kg} \mathrm{ha}^{-1} \mathrm{~mm}^{-1}\right)$. Hence, the research provides clear evidence that the irrigation of winter wheat with magnetized and/or oxidized water can increase grain yields and WUE.
\end{abstract}

Keywords: magnetization; oxidation; root vigor; root length density; grain yields; water-use efficiency

\section{Introduction}

The shortage of water resources on a global level limits agricultural development, and may severely threaten global food security in the coming decades [1-3]. The oppositional juxtaposition between growing demand for production and water shortages has become increasingly prominent in agricultural production $[4,5]$. Wheat production has stagnated in $37 \%$ and $56 \%$ of the production areas around the world and in China, respectively [6]. 
Most of the areas dedicated to winter wheat production in China are characterized by the uneven distribution of water resources over time and space, while the period of crop growth is not usually synchronized with the rainy season [7]. Both of these characteristics mean that these regions of winter wheat production are highly dependent on irrigation with groundwater [8]. This deep irrigation and exploitation of groundwater resources adversely affected the region $[9,10]$, with the water table decreasing by $0.5-3 \mathrm{~m} /$ year in the northwest part of China over the last 20 years [11]. Furthermore, the use of surface irrigation methods (furrow and border irrigation) and excessive water consumption in agricultural production translate to especially low water-use efficiency (WUE) and irrigation water-use efficiency (IWUE) in northwestern China [12,13]. Hence, it is imperative that agricultural organizations and researchers in these areas explore efficient, environmentally friendly agricultural technologies that will improve crop productivity and WUE while conserving water and the local environment. The identification of effective solutions will greatly help the region transition to sustainable agriculture.

Magnetized water production has begun to attract significant attention from the agricultural sector [14,15], mainly because it can alter the molecular structure of water and the composition of the aquatic environment through a physical technique $[16,17]$. Furthermore, it can improve the capacity for water to interact with other substances [18]. Water becomes magnetized after flowing through the magnetic environment comprising permanent magnets of a certain velocity positioned perpendicular to the magnetic force line. Studies have indicated that the magnetic treatment of irrigation water can benefit crop growth and yield along with water properties, which could make it possible to utilize lower quality water in agriculture $[19,20]$. Treatment approaches relying on oxidation have also been tested in agriculture, and irrigation with oxidized water has demonstrated promising results $[21,22]$. Although multiple studies have shown that magnetized water can promote the growth and yield of crops such as wheat, corn and soybean, there are still doubts about how effective this practice is [20,23-25]. Most skeptics state that the biological effects of magnetized water, as well as the mechanisms through which it improves growth and yield, remain unclear, which limits its application to agriculture. The oxidized water refers to water which only retains the positive charge and positive ions after being passed through an oxidation system. Several systematic studies have highlighted various examples of how using oxidized water to irrigate crops can benefit agriculture. For example, Wang et al. [18] showed that irrigation with oxidized water can improve WUE, reduce soil salt stress and increase yields. Irrigation water that has been improved by physical technology can be defined as activated water. By improving the physicochemical properties (the $\mathrm{pH}$ and dissolved oxygen concentration of water increase after activation, while the viscosity coefficient and surface tension decrease), the magnetic or oxidation treatment improves the action, and ultimately advances the transmission, of irrigation water from soil to crops. The size of crystalline particles and sedimentation after treatment will reduce, and more particles will be suspended in the water. This will decrease the likelihood of precipitated solid substances blocking irrigation and crop capillary channels, and help maintain a smooth flow of nutrient solution, thus enhancing the absorption of water by plants [25].

The root system is the primary organ through which plants uptake available water and nutrients $[9,26,27]$. The roots of winter wheat are affected by soil water status [28,29], and improvements in soil water use efficiency mainly depend on the development of the root system $[1,30]$. Various irrigation practices can stimulate roots to grow into deeper soil layers, and thus, can enhance the uptake of water from the subsoil layers [31]. The key root morphological characteristics are root length density, root weight density and root surface area density, all of which directly influence the functioning of the root system and crop production $[9,32]$. Root growth was found to be significantly associated with shoot biomass, which contributes to higher grain yields and WUE [33].

The Guanzhong Plain is a typical irrigated area located in the middle of Shaanxi Province and is the main area for winter wheat production within China. Spring and summer droughts, which are influenced by the monsoon climate and exacerbated by the 
intensified exploitation of water, have seriously decreased winter wheat yields on the plain. This has severely restricted the development of sustainable agriculture in the area [12]. Therefore, the area needs efficient technological solutions that can improve crop yields and WUE under water limitations and serve as a basis for sustainable agricultural development. Up to now, the response of crop root growth and physiological characteristics to activated water irrigation needs to be clarified. The main purpose of this study was to clarify the how winter wheat responds to irrigation with water that has been treated with magnetization and oxidation, as well as a combination of the two. More specifically, root morphology and vigor were studied in hydroponic experiments, while grain yields and WUE were studied via field experiments. We hoped to provide insight into how irrigation with magnetized and/or oxidized water can benefit winter wheat production.

\section{Materials and Methods}

\subsection{Site Description and Experimental Design}

\subsubsection{Hydroponic Experiments}

Hydroponic experiments were carried out in a greenhouse of Northwest Agricultural and Forestry University, Shannxi Province, China, between June-September 2019. The Xiaoyan 22 wheat variety was tested.

Both pure groundwater (mineralization degree of $0.14 \mathrm{~g} / \mathrm{L}$ ) and brackish water (mineralization degree of $3 \mathrm{~g} / \mathrm{L}$, composed of $\mathrm{NaCl}$ and pure groundwater) were tested. They were subjected either to magnetization or oxidation, or both. The water pass through the magnetization or oxidation circulatory system for $0.5 \mathrm{~h}$. The experiments also included controls for both types of water. Following treatment, the water was used to prepare a nutrient solution that would be used in the hydroponic cultivation system [34]. The experimental design is shown in Table 1.

Table 1. The different water treatment schemes applied in the hydroponic experiments.

\begin{tabular}{ccc}
\hline \multirow{2}{*}{ Treatment } & \multicolumn{2}{c}{ Test Water } \\
\cline { 2 - 3 } & Pure Groundwater & Brackish Water \\
\hline CK & $\mathrm{CK}-\mathrm{G}$ & $\mathrm{CK}-\mathrm{B}$ \\
Magnetization & $\mathrm{GM}$ & $\mathrm{BM}$ \\
Oxidation & $\mathrm{GO}$ & $\mathrm{BO}$ \\
Magnetization + oxidation & $\mathrm{G}(\mathrm{M}+\mathrm{O})$ & $\mathrm{B}(\mathrm{M}+\mathrm{O})$ \\
Oxidation + magnetization & $\mathrm{G}(\mathrm{O}+\mathrm{M})$ & $\mathrm{B}(\mathrm{O}+\mathrm{M})$ \\
\hline
\end{tabular}

Note: $\mathrm{CK}$ means the control check. $\mathrm{CK}-\mathrm{G}$ and $\mathrm{CK}-\mathrm{B}$ mean that the wheat received groundwater and brackish water, respectively, without any treatment. GM and GO describe cultivation with groundwater that was magnetized and oxidized, respectively. $\mathrm{G}(\mathrm{M}+\mathrm{O})$ and $\mathrm{G}(\mathrm{O}+\mathrm{M})$ describe cultivation with groundwater that was magnetized and then oxidized and groundwater that was oxidized and then magnetized, respectively. $\mathrm{BM}, \mathrm{BO}$, $\mathrm{B}(\mathrm{M}+\mathrm{O})$ and $\mathrm{B}(\mathrm{O}+\mathrm{M})$ describe the aforementioned treatments, with the exception of using brackish water.

Seeds that were clean and of uniform size were selected for conventional seedling cultivation. The seeds were washed after being soaked in hydrogen peroxide, and then placed in a dish with filter paper at the bottom. Each treatment had five replicates, and each treatment contained 300 seeds. The water was replaced once a day with water from various treatments. After five days, the seedlings with consistent and robust growth were selected and cultivated with the nutrient solution prepared from the treated water [34]. The cultivation conditions were: temperature of $25^{\circ} \mathrm{C} / 20^{\circ} \mathrm{C}$ (day/night); humidity between $60-70 \%$; natural light; and the nutrient solution was changed every five days. The volume of the nutrient solution in cultivation box was $5000 \mathrm{~cm}^{3}$. The experiment had a complete randomized block design, and each treatment (containing 45 wheats) had five replicates.

\subsubsection{Field Experiments}

Field experiments were performed to assess how different irrigation water types affected crop growth and WUE. The field experiments were carried out during 2018-2019 and 2019-2020 at the Caoxinzhuang experimental farm of the Northwest Agricultural and 
Forestry University on the Guanzhong Plain at the southern end of the Loess Plateau, China $\left(34^{\circ} 18^{\prime} \mathrm{N}, 108^{\circ} 05^{\prime} \mathrm{E}, 523.7 \mathrm{~m}\right.$ above sea level). The area has a mean annual temperature of $12.9^{\circ} \mathrm{C}$ and mean annual precipitation of $650 \mathrm{~mm}$. Most of the precipitation, which accounts for $65 \%$ of total annual precipitation, is concentrated between July-September. The day, monthly precipitation and precipitation frequency of rain events for various precipitation classes are presented in Figure 1. The available phosphorous, hydrolysable nitrogen and available potassium in the $0-20 \mathrm{~cm}$ layer before the experiment were $5.7 \mathrm{mg} \mathrm{kg}^{-1}$, $7.0 \mathrm{mg} \mathrm{kg}^{-1}$ and $133.8 \mathrm{mg} \mathrm{kg}^{-1}$, respectively. The sand content, silt content and clay content were $31.8 \%, 51.7 \%$ and $16.5 \%$, respectively. The winter-wheat cultivar Xiaoyan 22 used in this experiment is widely grown in this area. The wheat was sown on 15 October 2018 and 13 October 2019 at a planting density of $187.5 \mathrm{~kg} \mathrm{ha}^{-1}$.

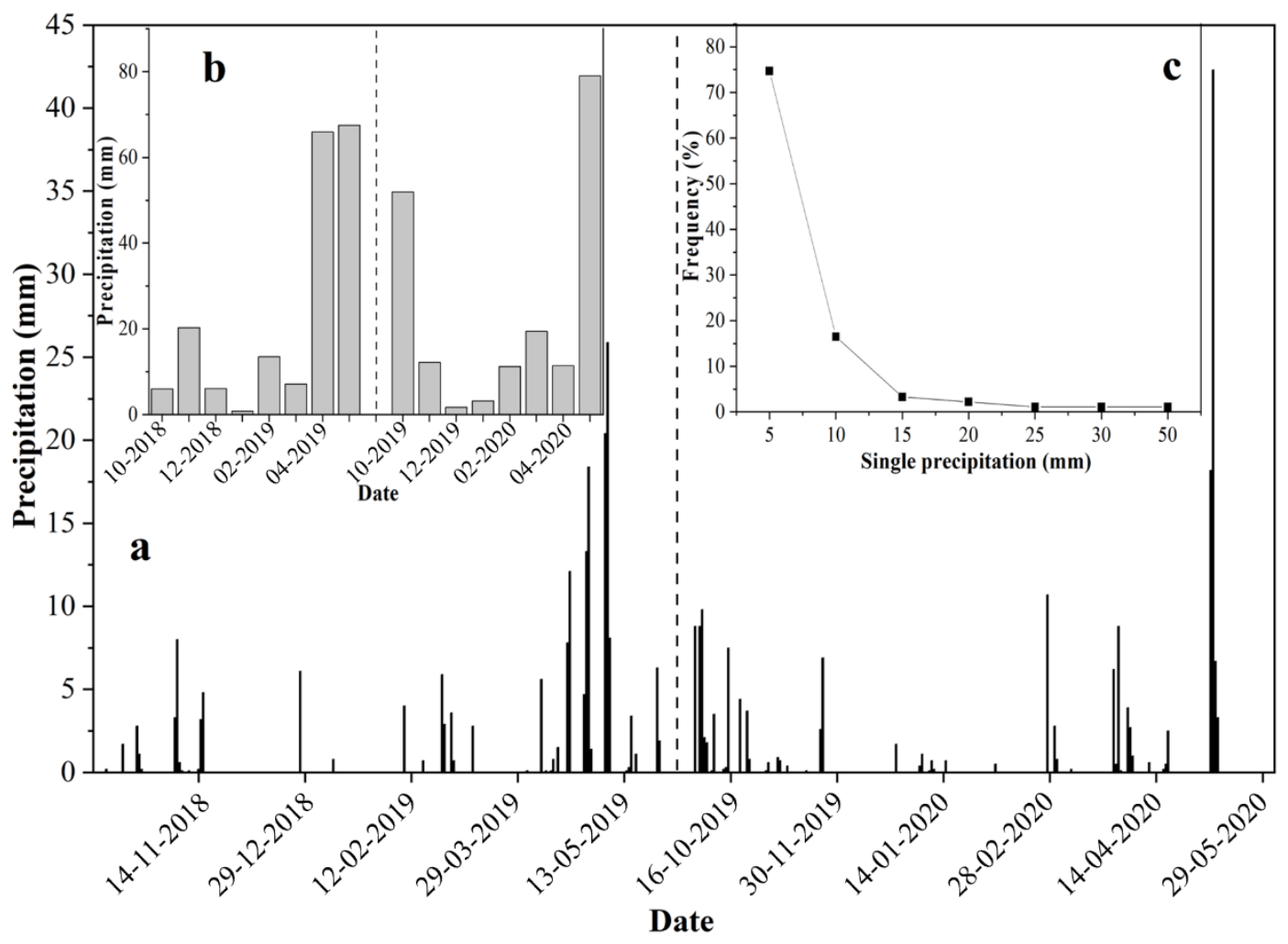

Figure 1. The daily (a) and monthly (b) precipitation and precipitation frequency (c) during the winter wheat growth period from October 2018 to June 2019 and from October 2019 to June 2020 in field experiments.

The mineralization degree of the local groundwater is $0.14 \mathrm{~g} / \mathrm{L}$. The artificial preparation of brackish water for irrigation can lead to soil salinization and destroy the soil environment. Therefore, brackish water irrigation experiments were not carried out, and only pure groundwater was used for the irrigation experiments. Five different types of irrigation water differing in treatment were tested during the overwintering (15 January 2019 and 2 January 2020, respectively), jointing (3 April 2019 and 23 March 2020, respectively) and filling (20 May 2019 and 22 May 2020, respectively) stages of wheat production (Table 2). The single irrigation amount was $60 \mathrm{~mm}$, while the total irrigation amount was $180 \mathrm{~mm}$. The drip irrigation system was used, and the irrigation levels were calculated by the number of taps and the drip rate. The experiment employed a complete randomized block design, and each treatment had three replicates [35]. Each plot was $4 \mathrm{~m} \times 4 \mathrm{~m}$, and adjacent plots were separated by $1 \mathrm{~m}$. 
Table 2. The treatments and irrigation parameters used in the field experiments.

\begin{tabular}{cccc}
\hline & Type of Irrigation Water & $\begin{array}{c}\text { Single Irrigation } \\
\text { Amount (mm) }\end{array}$ & $\begin{array}{c}\text { Total Irrigation } \\
\text { Amount (mm) }\end{array}$ \\
\hline IG & Pure groundwater & 60 & 180 \\
IGM & Magnetized water & 60 & 180 \\
IGO & Oxidized water & 60 & 180 \\
IG(M+O) & Magnetized + oxidized water & 60 & 180 \\
IG(O+M) & Oxidized + magnetized water & 60 & 180 \\
\hline
\end{tabular}

Note: IG means irrigation with pure groundwater. IGM and IGO describe irrigation with magnetized and oxidized groundwater, respectively, and the total irrigation amount is $180 \mathrm{~mm}$. IG $(\mathrm{M}+\mathrm{O})$ and $\mathrm{IG}(\mathrm{O}+\mathrm{M})$ describe irrigation with groundwater that was magnetized and then oxidized and irrigation with groundwater that was oxidized and then magnetized, respectively.

\subsection{Magnetization and Oxidation of Water}

The system for magnetizing water consisted of a water-supply tank, pump, outlet pipe (polyethylene pipe) and magnet. A permanent magnet $(20 \mathrm{~cm}$ length, $10 \mathrm{~cm}$ height, $8 \mathrm{~cm}$ width) with a field intensity of $3000 \mathrm{G}$ was used in this study. The permanent magnet was mounted on the outer wall of the outlet pipe (about $1.0 \mathrm{~m}$ from the water outlet), and the water was magnetized as it passed through the pipe (The thickness and diameter of the pipe were $0.5 \mathrm{~cm}$ and $10.0 \mathrm{~cm}$, respectively). Flow rate was $6.3 \times 10^{-3} \mathrm{~m}^{3} / \mathrm{s}$. The oxidation system included an oxidation processor (Eco1st Technology Group, http:// irrigationenhancer.com/ (accessed on 20 May 2018)), grounding resistance, wire and pump. As water flowed along the oxidation processor, the walls became enriched with electrons, which were then channeled underground to the electrode through grounded wires.

\subsection{Sampling and Analysis}

\subsubsection{Hydroponic Plant Indices}

The chlorophyll content of hydroponic wheat leaves was measured in SPAD (soil plant analysis development) units. The SPAD values of the flag leaves were measured with a SPAD-502 Minolta chlorophyll meter (Spectrum Technologies, Plainfield, IL, USA), with 10 leaves subjected to measurements at every sampling point.

At the jointing stage, the roots of five plants from each hydroponic tank were randomly selected to measure root vigor. Fresh $0.5 \mathrm{~g}$ root tip samples were taken from each wheat plant. The root vigor of wheat was assessed by measuring the amount of triphenyl tetrazolium chloride (TTC) in the roots [36,37].

Root samples were collected from wheat plants at the jointing stage, grown in each of the water types described in Table 1. The live roots were carefully separated from dead roots according to instructions by Gregory [38]. The images at a resolution of $300 \mathrm{dpi}$ were obtained by scanning with Epson scanner (version V370, Epson, Inc., Beijing City, China). WinRHIZO software (version 5.0, Regent Instruments, Inc., Quebec City, QC, Canada) was used to determine root length, root surface area and root diameter from root images. The root tissue density, root fineness, root length ratio, root mass ratio, root length density, root weight density, root surface area density and root/shoot ratio were calculated based on equations presented by Shahzad et al. [39].

\subsubsection{Soil Water Content and Soil Water Storage under Field Experiments}

The volumetric soil water content (SWC) was monitored from the center of each plot at the greening, jointing, filling and maturity stages at $10-\mathrm{cm}$ intervals to a depth of $3 \mathrm{~m}$ using a neutron meter (IH-II, Didcot Instrument Co., Wallingford, UK) on the field plots with three replicates. The neutron probe could reach this depth by inserting it through a tube while connected to the neutron meter on the surface via a wire. Firstly, the calibration curve of soil volumetric water content in the study area was obtained, and then the soil volumetric water content of $0-300 \mathrm{~cm}$ soil layers was calculated according to the calibration curve. Soil water content was measured every 15 days. If it rained on the planned sampling date, the sampling was appropriately delayed. The maximum root depth of the wheat 
during flowering was $>2.0 \mathrm{~m}$, so monitoring SWC at a depth of $3 \mathrm{~m}$ was conducive to analyzing deep soil water differences $[40,41]$. The SWC was determined by weighing the samples before and after oven-drying [26].

Soil water storage was calculated using the following equation [42,43]:

$$
\text { SWS }=\sum_{i}^{n} h_{i} \times \rho_{i} \times b_{i} \times 10 / 100
$$

where SWS $(\mathrm{mm})$ is soil water storage, $\mathrm{h}_{\mathrm{i}}(\mathrm{cm})$ is the thickness of the soil layer, $\rho_{\mathrm{i}}\left(\mathrm{g} \mathrm{cm}^{-3}\right)$ is the bulk density in each layer, $b_{i}$ is the percentage of soil water by weight, $n$ is the number of soil layers and $i=10,20,40, \ldots, 300$. To ensure the accuracy of the bulk density, we excavated a $3 \mathrm{~m}$ deep profile in the center of the study area for stratified sampling.

\subsubsection{Wheat Production}

Plant samples were randomly collected from a $1.0 \mathrm{~m}^{2}$ section in each plot to measure spike number, grains per spike, 1000-grain weight and grain yield at maturity [5].

\subsubsection{Soil Water Consumption, WUE and IWUE}

Crop evapotranspiration (ET) during growth was calculated using the water-balance equation [44]:

$$
\mathrm{ET}=\mathrm{P}+\mathrm{I}+(\mathrm{SWS} 1-\mathrm{SWS} 2)-\mathrm{D}-\mathrm{R}
$$

where ET $(\mathrm{mm})$ is the crop evapotranspiration, $\mathrm{P}(\mathrm{mm})$ is total rainfall during the growing season, I ( $\mathrm{mm})$ is the total amount of irrigation, SWS1 $(\mathrm{mm})$ is SWS at planting, SWS2 is SWS at harvest, $\mathrm{D}$ is deep percolation of soil water below the measurement depth and $\mathrm{R}$ is the surface runoff. The groundwater table remained at a depth of about $100 \mathrm{~m}$ below the surface during the experiment based on well monitoring around the study area, so capillary water which moves up from the deep layer to the root zone could be neglected. According to Lin et al. [45], the amount of rainfall was not enough to percolate into the soil layer below $300 \mathrm{~cm}$ depth. Additionally, we measured soil water content in the $0-300 \mathrm{~cm}$ layer, and calculated available soil water to a depth of $300 \mathrm{~cm}$, so D could also be neglected. Runoff was never observed because the experimental field was flat.

WUE and IWUE were calculated using the following equations [1]:

$$
\begin{gathered}
\text { WUE }=\mathrm{Y} / \mathrm{ET} \\
\mathrm{IWUE}=\mathrm{Y} / \mathrm{I}
\end{gathered}
$$

where WUE $\left(\mathrm{kg} \mathrm{ha}^{-1} \mathrm{~mm}^{-1}\right)$ describes water-use efficiency for grain yield and IWUE $\left(\mathrm{kg} \mathrm{ha}^{-1} \mathrm{~mm}^{-1}\right)$ describes the irrigation water-use efficiency. $\mathrm{Y}\left(\mathrm{kg} \mathrm{ha}^{-1}\right)$ is grain yield at maturity.

\subsection{Statistical Analyses}

Prior to the analysis, we tested the normality and homogeneity of variances of the experimental data. The mean values were calculated for each variable and analysis of variance (ANOVA) was used to assess the significance of differences in the measured variables between treatments. If the F-value was significant $(p<0.05)$, multiple comparisons of annual mean values were performed based on the least significant difference (LSD). All of these analyses were performed in SPSS (Statistical Product and Service Solutions, version 13.0, IBM Corporation, Armonk, NY, USA). The graphs were prepared in OriginPro 2016 (OriginLab Corporation, Northampton, MA, USA). 


\section{Results}

\subsection{Root Growth under Hydroponic Conditions}

\subsubsection{Germination Proportion}

The proportions of wheat seeds that germinated after hydroponic cultivation with pure groundwater and brackish water subjected to different treatments are shown in Figure 2. The hydroponically-cultivated plants receiving magnetized and oxidized water showed germination proportions that were $24.8 \%$ and $31.1 \%$ higher, respectively, than what was observed for pure groundwater $(\mathrm{CK}-\mathrm{G})$, and $20.9 \%(\mathrm{BM})$ and $31.8 \%(\mathrm{BO})$ higher, respectively, than what was observed for untreated brackish water $(\mathrm{CK}-\mathrm{B})$. The germination proportions for $\mathrm{B}(\mathrm{M}+\mathrm{O})$ and $\mathrm{B}(\mathrm{O}+\mathrm{M})$ were $50.0 \%$ and $51.7 \%$, respectively. These ratios were $36.4 \%$ and $40.9 \%$ higher, respectively, than the proportion observed for $\mathrm{CK}-\mathrm{B}$ $(p<0.05)$. With the exception of the BM treatment, plants which had been treated with magnetized water, oxidized water or a combination of both showed significantly higher germination proportions than $\mathrm{CK}-\mathrm{G}$ or $\mathrm{CK}-\mathrm{B}(p<0.05)$ plants.

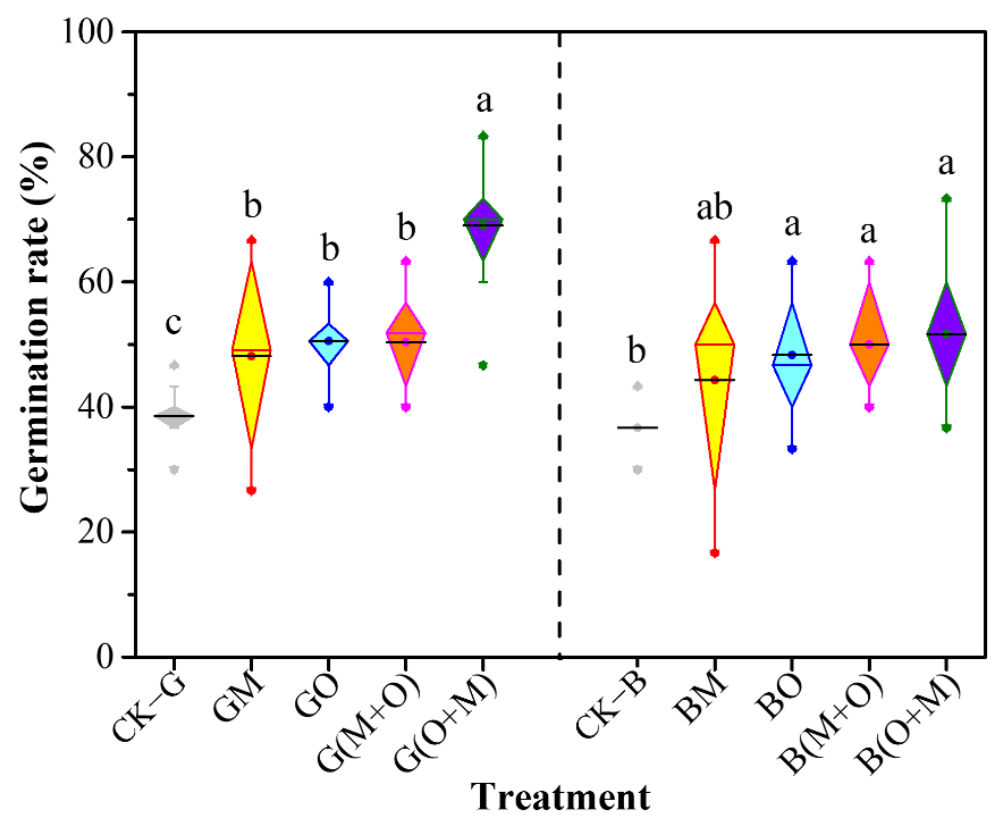

Figure 2. Effects of different water treatments on germination proportions of winter wheat. Analysis of variance (ANOVA) was used to assess the significance of differences in the measured variables between treatments. Different letters above the bars on both sides of the dashed line indicate significant between-treatment differences at $p<0.05$. Note: The black horizontal line and the color horizontal line represent the mean and median, respectively.

\subsubsection{Root Vigor}

As shown in Figure 3, both water treatment approaches significantly improved root vigor in winter wheat, with the TTC scores of roots treated with magnetized and oxidized water $100.5-253.7 \%$ and $100.4-213.9 \%$ higher, respectively, than what was measured for control plants $(\mathrm{CK}-\mathrm{G}$ and $\mathrm{CK}-\mathrm{B} ; p<0.05)$. However, the two treatments did not differ significantly in root vigor when only comparing plants under the same water class (groundwater or brackish; $p>0.05)$. The GO $\left(925.1 \mu \mathrm{g} \mathrm{g}^{-1} \mathrm{~h}^{-1}\right)$ and $\mathrm{B}(\mathrm{O}+\mathrm{M})\left(775.2 \mu \mathrm{g} \mathrm{g}^{-1} \mathrm{~h}^{-1}\right)$ treatments showed the highest root vigor values in the groundwater and brackish water hydroponic systems, respectively. For both types of water, oxidation had a larger impact on root vigor than the magnetic treatment. As such, the root vigor of plants that had received water that was first oxidized and then magnetized $(\mathrm{G}(\mathrm{O}+\mathrm{M})$ and $\mathrm{B}(\mathrm{O}+\mathrm{M}))$ differed slightly from the root vigor of plants that had received water which was first magnetized and then oxidized $(\mathrm{G}(\mathrm{M}+\mathrm{O})$ and $\mathrm{B}(\mathrm{M}+\mathrm{O}))$. Hence, both of the tested treatment methods 
can improve wheat root vigor relative to untreated groundwater or brackish water, with oxidation having a more significant effect than magnetization.

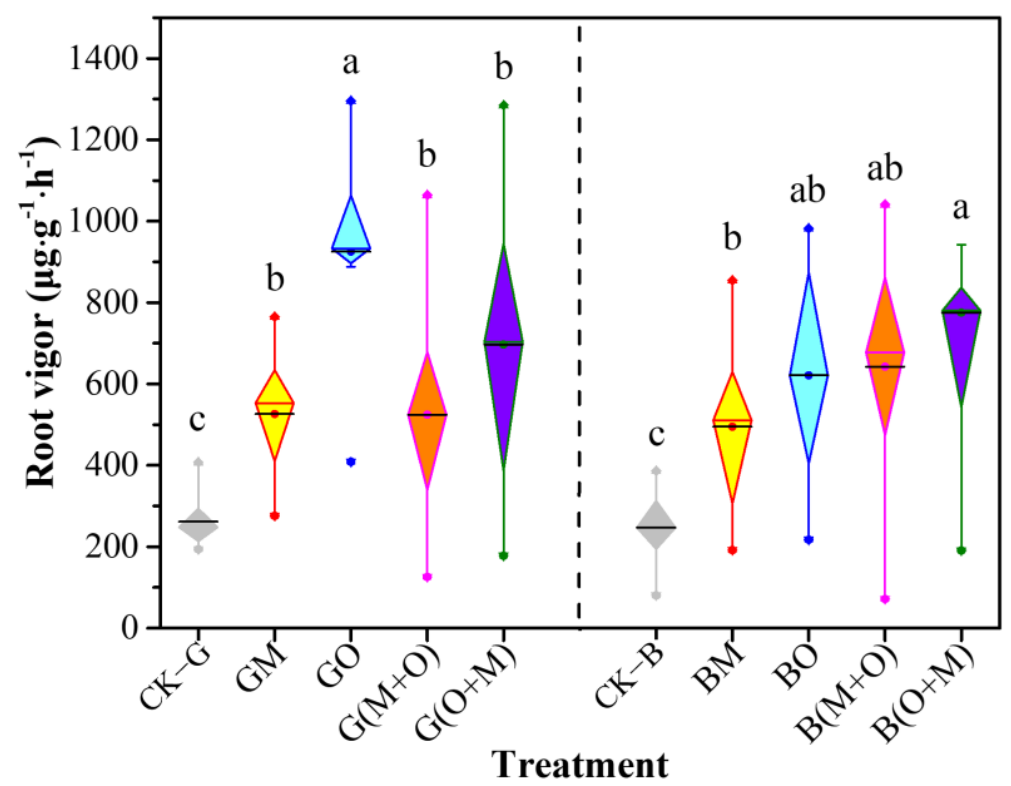

Figure 3. Root vigor of winter wheat cultivated in a hydroponic system with pure groundwater and brackish water that was subjected to two different treatments (magnetization and oxidation). Different letters above the bars on both sides of the dashed line indicate significant between-treatment differences at $p<0.05$. Note: The black horizontal line and the color horizontal line represent the mean and median, respectively.

\subsubsection{Root Length Density (RLD), Root Weight Density (RWD) and Root Surface Area Density (RSD)}

There were significant differences between the water types regarding how the treatment methods affected RLD (Table 3). The treatment methods had a more significant effect in the groundwater hydroponic system than in the brackish water hydroponic system. For example, the RLD of wheat roots increased by $67.6 \%$ and $79.4 \%$ by the GM and GO treatments, respectively, from the control group $(\mathrm{CK}-\mathrm{G})$. The corresponding changes for $\mathrm{BM}$ and $\mathrm{BO}$ - from $\mathrm{CK}-\mathrm{B}$ - were $7.5 \%$ and $40.0 \%$, respectively. With brackish water, the largest increase in $\mathrm{RLD}, 57.5 \%$ higher than for $\mathrm{CK}-\mathrm{B}$, was observed in the $\mathrm{B}(\mathrm{O}+\mathrm{M})$ treatment.

Table 3. Root length density (RLD), root weight density (RWD) and root surface area density (RSD) of wheat receiving either groundwater or brackish water subjected to two treatment methods.

\begin{tabular}{|c|c|c|c|c|}
\hline & Treatment & $\begin{array}{l}\text { Root Length } \\
\text { Density } \\
\left(\mathrm{cm} \mathrm{cm}^{-3}\right)\end{array}$ & $\begin{array}{c}\text { Root Weight } \\
\text { Density } \\
\left(\times 10^{-5} \mathrm{~g} \mathrm{~cm}^{-3}\right)\end{array}$ & $\begin{array}{c}\text { Root Surface } \\
\text { Area Density } \\
\left(\mathrm{cm}^{2} \mathrm{~cm}^{-3}\right)\end{array}$ \\
\hline \multirow{5}{*}{$\begin{array}{c}\text { Pure } \\
\text { groundwater }\end{array}$} & $\mathrm{CK}-\mathrm{G}$ & $0.34 \mathrm{c}$ & $3.31 \mathrm{~b}$ & $0.04 \mathrm{~d}$ \\
\hline & GM & $0.57 \mathrm{ab}$ & $5.75 \mathrm{a}$ & $0.07 \mathrm{bc}$ \\
\hline & $\mathrm{GO}$ & $0.61 \mathrm{a}$ & $5.82 \mathrm{a}$ & $0.09 \mathrm{a}$ \\
\hline & $\mathrm{G}(\mathrm{M}+\mathrm{O})$ & $0.63 \mathrm{a}$ & $5.35 \mathrm{a}$ & $0.08 \mathrm{ab}$ \\
\hline & $\mathrm{G}(\mathrm{O}+\mathrm{M})$ & $0.42 \mathrm{~b}$ & $4.14 \mathrm{~b}$ & $0.06 \mathrm{c}$ \\
\hline \multirow{5}{*}{$\begin{array}{c}\text { Brackish } \\
\text { water }\end{array}$} & $\mathrm{CK}-\mathrm{B}$ & $0.40 \mathrm{~b}$ & $2.49 \mathrm{~b}$ & $0.05 \mathrm{~b}$ \\
\hline & $\mathrm{BM}$ & $0.43 a b$ & $3.48 \mathrm{a}$ & $0.06 \mathrm{~b}$ \\
\hline & $\mathrm{BO}$ & $0.56 \mathrm{ab}$ & $4.15 \mathrm{a}$ & $0.07 \mathrm{ab}$ \\
\hline & $\mathrm{B}(\mathrm{M}+\mathrm{O})$ & $0.44 \mathrm{ab}$ & $3.69 \mathrm{a}$ & $0.05 \mathrm{~b}$ \\
\hline & $\mathrm{B}(\mathrm{O}+\mathrm{M})$ & $0.63 \mathrm{a}$ & $3.87 \mathrm{a}$ & $0.10 \mathrm{a}$ \\
\hline
\end{tabular}


Table 3. Cont.

\begin{tabular}{|c|c|c|c|c|}
\hline & Treatment & $\begin{array}{l}\text { Root Length } \\
\text { Density } \\
\left(\mathrm{cm} \mathrm{cm}^{-3}\right)\end{array}$ & $\begin{array}{c}\text { Root Weight } \\
\text { Density } \\
\left(\times 10^{-5} \mathrm{~g} \mathrm{~cm}^{-3}\right)\end{array}$ & $\begin{array}{c}\text { Root Surface } \\
\text { Area Density } \\
\left(\mathrm{cm}^{2} \mathrm{~cm}^{-3}\right)\end{array}$ \\
\hline \multirow{3}{*}{$\mathrm{F}$-value } & Water quality & 1.01 & $51.85^{* *}$ & 0.31 \\
\hline & Activation methods & 2.40 & $12.72 * *$ & 2.20 \\
\hline & $\begin{array}{c}\text { Water quality } \times \\
\text { Activation methods }\end{array}$ & $8.18^{* *}$ & $5.93 *$ & $12.49^{* *}$ \\
\hline
\end{tabular}

Different letters in the same column indicate significant between-treatment differences at $p<0.05 .{ }^{*}$ and ${ }^{* *}$ indicate significant differences at the 0.05 and 0.01 probability levels, respectively.

The relative effect of the treatment methods depended on the type of water treated (Table 3). With groundwater, the RWD obtained with GM and GO was 73.7\% and 75.8\% larger than the $\mathrm{CK}-\mathrm{G}(p<0.05)$. With brackish water, the RWD obtained with $\mathrm{BM}, \mathrm{BO}, \mathrm{B}(\mathrm{M}+\mathrm{O})$ and $\mathrm{B}(\mathrm{O}+\mathrm{M})$ were $39.8 \%, 66.7 \%, 48.2 \%$, and $55.4 \%$ higher, respectively, than the $\mathrm{CK}-\mathrm{B}$ $(p<0.05)$. The tested treatment methods had a larger effect on the RSD of wheat root in groundwater than in brackish water cultivation systems, with a maximum increase of $0.09 \mathrm{~cm}^{2} \mathrm{~cm}^{-3}$ observed for the GO treatment. In brackish water, $\mathrm{B}(\mathrm{O}+\mathrm{M})$ had the largest effect on RSD-100.0\% higher than measured for CK-B.

\subsubsection{Root Morphology}

The root morphology parameters (except for root fineness) were significantly different across the water types and treatment methods $(p<0.05)$, while the variation between water types was not significant except for dry root weight (Table 4). The GO and G(O+M) treatments significantly increased the root tissue density (36.7\% and $35.0 \%)$, root fineness $(21.9 \%$ and $26.3 \%)$, root length ratio $(67.2 \%$ and $44.1 \%)$, and root mass ratio $(69.2 \%$ and $53.8 \%$ ) relative to $\mathrm{CK}-\mathrm{G}$. Compared to $\mathrm{CK}-\mathrm{B}$, the dry root weight of $\mathrm{BM}, \mathrm{BO}, \mathrm{B}(\mathrm{M}+\mathrm{O})$ and $\mathrm{B}(\mathrm{O}+\mathrm{M})$ treatments increased significantly, i.e., by $41.7 \%, 75.0 \%, 58.3 \%$, and $50.0 \%$, respectively. The $\mathrm{BM}$ and $\mathrm{BO}$ treatments showed significant increase in root tissue density $(31.8 \%$ and $67.6 \%)$ and root mass ratio $(29.5 \%$ and $73.0 \%)$ relative to the $\mathrm{CK}-\mathrm{B}$ treatment. The root length ratios of $\mathrm{BM}, \mathrm{BO}, \mathrm{B}(\mathrm{M}+\mathrm{O})$ and $\mathrm{B}(\mathrm{O}+\mathrm{M})$ did not significantly increase over the $\mathrm{CK}-\mathrm{B}$ control case.

Table 4. Effects of different treatments on the morphology of the winter wheat root system at the late jointing stage.

\begin{tabular}{|c|c|c|c|c|c|c|}
\hline & Treatment & $\begin{array}{l}\text { Root } \\
\text { Dry Weight } \\
\left.\text { (g Plant }^{-1}\right)\end{array}$ & $\begin{array}{c}\text { Root Tissue } \\
\text { Density } \\
\left(\mathrm{g} \mathrm{cm}^{-3}\right)\end{array}$ & $\begin{array}{c}\text { Root } \\
\text { Fineness } \\
\left(\mathrm{cm} \mathrm{cm}^{-3}\right)\end{array}$ & $\begin{array}{c}\text { Root Length } \\
\text { Ratio } \\
\left(\mathrm{cm} \mathrm{g}^{-1}\right)\end{array}$ & $\begin{array}{c}\text { Root Mass } \\
\text { Ratio } \\
\left(\mathrm{g} \mathrm{g}^{-1}\right)\end{array}$ \\
\hline \multirow{5}{*}{$\begin{array}{c}\text { Pure } \\
\text { groundwater }\end{array}$} & $\mathrm{CK}-\mathrm{G}$ & $0.17 \mathrm{~b}$ & $0.060 \mathrm{~b}$ & $641.55 \mathrm{~b}$ & $301.09 \mathrm{~b}$ & $0.026 \mathrm{~b}$ \\
\hline & GM & $0.28 \mathrm{a}$ & $0.066 \mathrm{ab}$ & $741.16 \mathrm{ab}$ & $400.06 \mathrm{ab}$ & 0.037 a \\
\hline & GO & $0.29 \mathrm{a}$ & $0.082 \mathrm{a}$ & $782.09 \mathrm{a}$ & $503.34 \mathrm{a}$ & $0.044 \mathrm{a}$ \\
\hline & $\mathrm{G}(\mathrm{M}+\mathrm{O})$ & $0.27 \mathrm{a}$ & $0.068 \mathrm{ab}$ & $802.18 \mathrm{a}$ & $399.33 \mathrm{ab}$ & $0.041 \mathrm{a}$ \\
\hline & $\mathrm{G}(\mathrm{O}+\mathrm{M})$ & $0.21 \mathrm{~b}$ & $0.081 \mathrm{a}$ & $810.40 \mathrm{a}$ & $433.96 \mathrm{a}$ & $0.040 \mathrm{a}$ \\
\hline \multirow{5}{*}{ Brackish water } & $C K-B$ & $0.12 \mathrm{~b}$ & $0.044 \mathrm{c}$ & $570.22 \mathrm{~b}$ & $605.92 \mathrm{a}$ & $0.037 \mathrm{~b}$ \\
\hline & $\mathrm{BM}$ & $0.17 \mathrm{a}$ & $0.058 \mathrm{ab}$ & 727.79 bc & $666.83 a$ & $0.062 \mathrm{a}$ \\
\hline & $\mathrm{BO}$ & $0.21 \mathrm{a}$ & $0.057 \mathrm{ab}$ & $898.06 \mathrm{a}$ & $761.68 \mathrm{a}$ & $0.064 \mathrm{a}$ \\
\hline & $\mathrm{B}(\mathrm{M}+\mathrm{O})$ & $0.19 \mathrm{a}$ & $0.067 \mathrm{a}$ & $814.88 \mathrm{ab}$ & $664.67 \mathrm{a}$ & $0.049 \mathrm{ab}$ \\
\hline & $\mathrm{B}(\mathrm{O}+\mathrm{M})$ & $0.18 \mathrm{a}$ & $0.050 \mathrm{bc}$ & $676.76 \mathrm{bc}$ & $741.25 \mathrm{a}$ & $0.044 \mathrm{ab}$ \\
\hline \multirow{3}{*}{$\mathrm{F}$-value } & Water quality & $51.38 * *$ & $20.99 * *$ & 0.46 & $72.85 * *$ & $23.67 * *$ \\
\hline & Activation methods & $15.44^{* *}$ & $3.20 *$ & $9.27^{* *}$ & $3.35 *$ & $8.08^{* *}$ \\
\hline & $\begin{array}{c}\text { Water quality } \times \\
\text { Activation methods }\end{array}$ & $3.06 *$ & 2.43 & 2.50 & 0.10 & 2.08 \\
\hline
\end{tabular}

Different letters in the same column indicate significant between-treatment differences at $p<0.05 .{ }^{*}$ and ${ }^{* *}$ indicate significant differences at the 0.05 and 0.01 probability levels, respectively. 


\subsubsection{Root/Shoot Ratios}

The root/shoot ratios of wheat under various treatments are shown in Figure 4. The results demonstrate that cultivating wheat with either pure groundwater or brackish water that has been subjected to magnetization and/or oxidation increased root/shoot ratios in winter wheat $(p<0.05)$. Compared to the $\mathrm{CK}-\mathrm{G}$ control case, the root/shoot ratios for the $\mathrm{GM}, \mathrm{GO}, \mathrm{G}(\mathrm{M}+\mathrm{O})$ and $\mathrm{G}(\mathrm{O}+\mathrm{M})$ treatments all improved significantly, i.e., by $42.4 \%$, $75.3 \%, 61.0 \%$, and $62.0 \%$, respectively. Figure 4 also shows that treated brackish water had a stronger effect on the root/shoot ratio (a maximum increase of $76 \%$ in the root/shoot ratio) than treated pure groundwater.

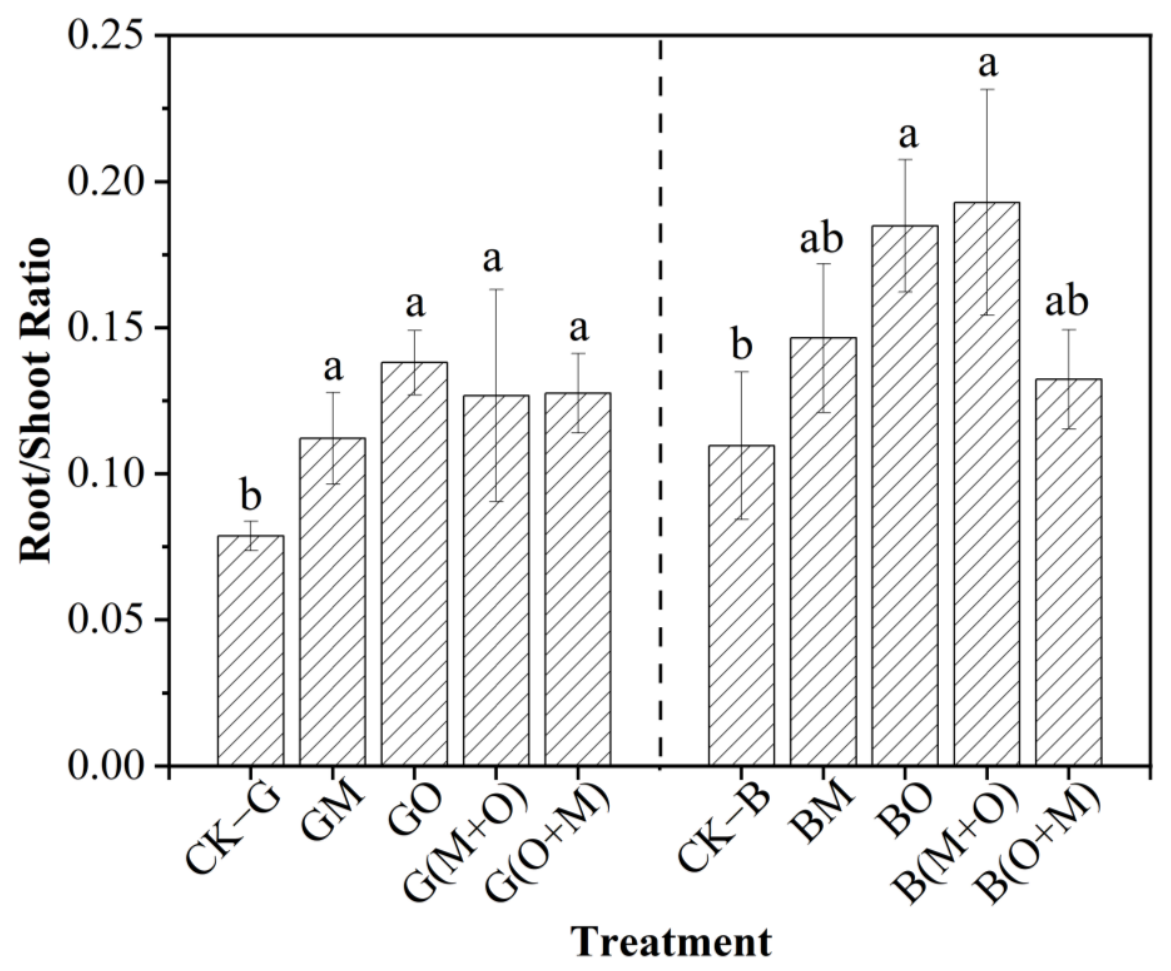

Figure 4. Root/shoot ratios of winter wheat for various treatments. Different letters above the bars on both sides of the dashed line indicate significant between-treatment differences at $p<0.05$.

\subsubsection{Chlorophyll Content (SPAD)}

In the groundwater hydroponic system, the leaves of winter wheat plants that had received water treated through magnetization and/or oxidation had significantly higher SPAD values (12.6-25.9\%) than the leaves of control on the 80th day of wheat cultivation $(p<0.05)$ (Figure 5). Plant leaves on the 110th day that received magnetized or oxidized brackish water had $14.5-25.0 \%$ higher SPAD than control leaves. Both the groundwater and brackish water cultivation systems demonstrated that the $\mathrm{GO}, \mathrm{BO}, \mathrm{G}(\mathrm{O}+\mathrm{M})$ and $\mathrm{B}(\mathrm{O}+\mathrm{M})$ treatments significantly improved the SPAD values of the leaves $(p<0.05)$.

\subsection{WUE of the Field Experiments} 3.2.1. SWC

As shown in Figure 6, the SWC $60 \mathrm{~cm}$ below ground surface in IGM, IGO, IG(M+O) and $\mathrm{IG}(\mathrm{O}+\mathrm{M})$ plots decreased to different degrees relative to control (IG) plots. At $150 \mathrm{~cm}$ below ground, the SWC for the IG $(\mathrm{M}+\mathrm{O})$ and $\mathrm{IG}(\mathrm{O}+\mathrm{M})$ were lower than in the IG case. The abundant rainfall from late April to early May may have been responsible for the high SWC observed in the 20-60 cm layer (Figure 1a). At the filling stage, soil water storage $(60-300 \mathrm{~cm})$ in the IGM and IGO plots was $11.6 \%$ and $13.9 \%$ lower, respectively, than what was observed in the control (IG) plot. Correspondingly, soil water storage $(60-300 \mathrm{~cm})$ in the IG $(\mathrm{M}+\mathrm{O})$ and $\mathrm{IG}(\mathrm{O}+\mathrm{M})$ plots at the filling stage was $16.7 \%$ and $16.9 \%$ lower, respectively, 
than what was observed for the control (IG) plot. In other words, the plots irrigated with either magnetized or oxidized water (or water that had been subjected to both treatments) could demonstrate higher water consumption or deeper penetration than plots irrigated with pure groundwater.

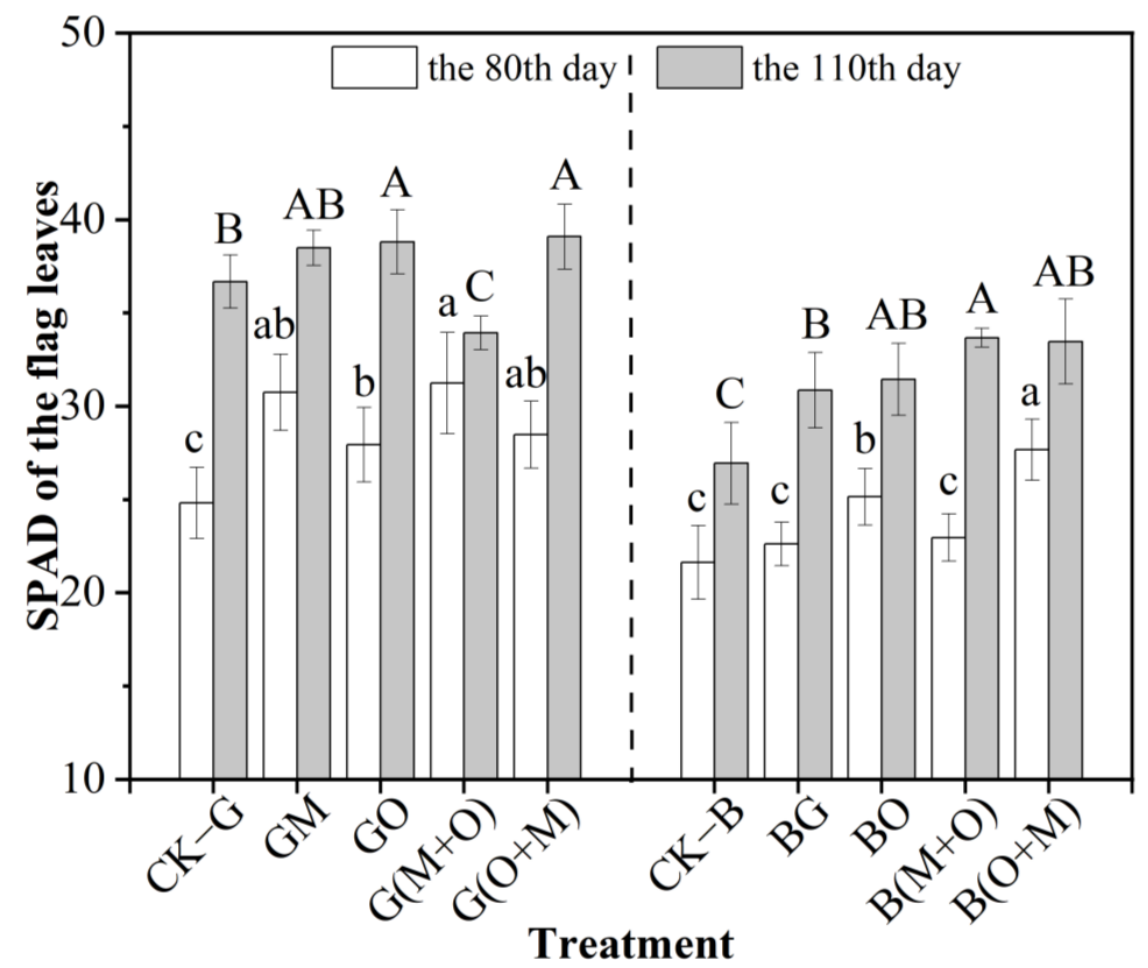

Figure 5. Soil plant analysis development (SPAD) of flag leaves 80 and 110 days after germination. Different letters above the bars on both sides of the dashed line indicate significant between-treatment differences at $p<0.05$.
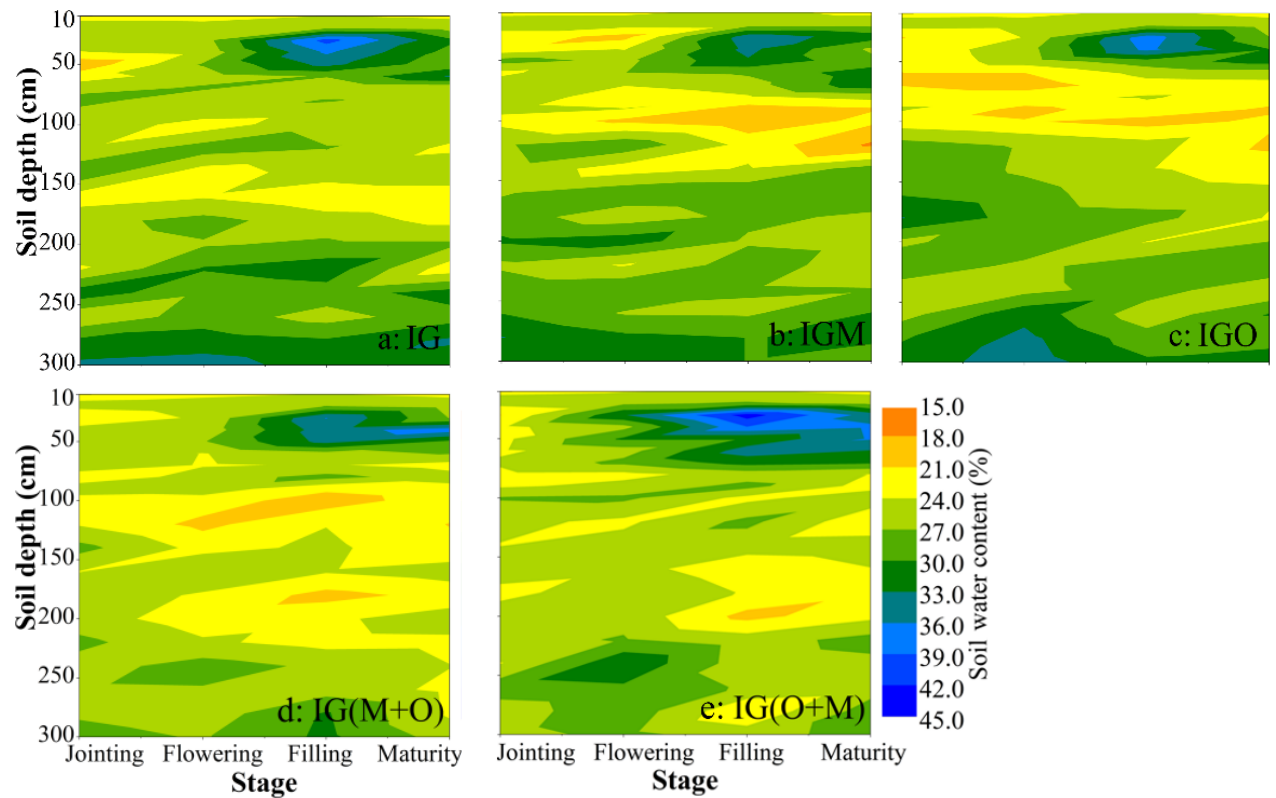

Figure 6. Contour maps of soil water content for plots irrigated with pure groundwater (a) IG treatment, magnetized water; (b) IGM treatment, oxidized water; (c) IGO treatment, magnetized + oxidized water; (d) $\mathrm{IG}(\mathrm{M}+\mathrm{O})$ treatment and oxidized + magnetized water; $(\mathbf{e}) \mathrm{IG}(\mathrm{O}+\mathrm{M})$ treatment during the period of rapid winter wheat growth (total irrigation amount: $180 \mathrm{~mm}$ ). 


\subsubsection{Yield, WUE and IWUE}

The yield, WUE and IWUE during the winter wheat growth period in the 2018-2019 and 2019-2020 season under different irrigation regimes are shown in Figure 7. The IGO plots provided yields that were $13.8 \%$ and $21.0 \%$ higher than the yield of the IG plots $(p<0.05)$, which translates to a difference of $10.7 \times 10^{3} \mathrm{~kg} \mathrm{ha}^{-1}$ and $11.7 \times 10^{3} \mathrm{~kg} \mathrm{ha}^{-1}$, respectively. Although the yield increased $(10.0 \%$ and $11.1 \%)$ when the pure groundwater used for irrigation was replaced with magnetized water (IGM), this result did not reach a level of statistical significance $(p>0.05)$. The IG $(\mathrm{O}+\mathrm{M})$ plots performed best in terms of WUE, $25.7 \%\left(30.3 \mathrm{~kg} \mathrm{ha}^{-1} \mathrm{~mm}^{-1}\right)$ and $21.8 \%\left(27.9 \mathrm{~kg} \mathrm{ha}^{-1} \mathrm{~mm}^{-1}\right)$ better than the control (IG) plots. When compared with IG plots, the IWUE of IGO plots in 2018-2019 and IGM plots in 2019-2020 increased by $13.9 \%$ and $21.0 \%\left(59.34 \mathrm{~kg} \mathrm{ha}^{-1} \mathrm{~mm}^{-1}\right.$ and $\left.97.33 \mathrm{~kg} \mathrm{ha}^{-1} \mathrm{~mm}^{-1}\right)$, respectively, with only the improvement reached by the IGM plots achieving statistical significance $(p<0.05)$.
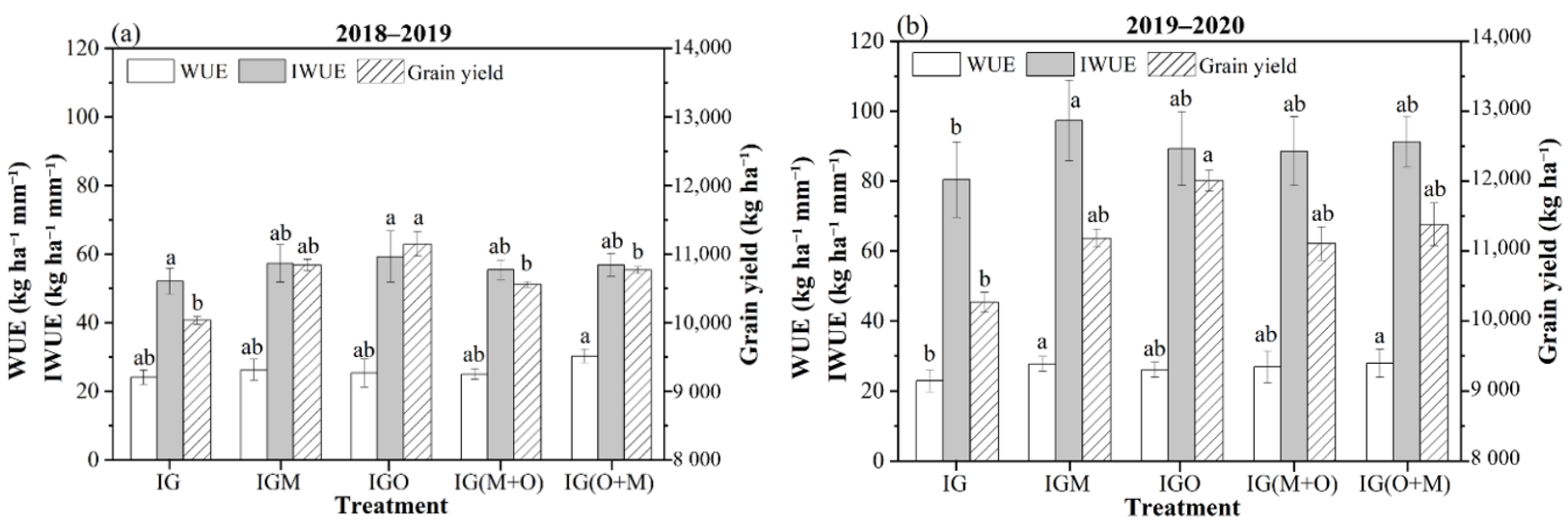

Figure 7. Grain yield, water-use efficiency (WUE) and irrigation water-use efficiency (IWUE) for winter wheat irrigated with water subjected to different treatments (pure groundwater (IG), magnetized water (IGM), oxidized water (IGO), magnetized + oxidized water $(\mathrm{IG}(\mathrm{M}+\mathrm{O}))$, and oxidized + magnetized water $(\mathrm{IG}(\mathrm{O}+\mathrm{M})$ ) during the 2018-2019 (a) and 20192020 (b) growing seasons. Different letters above the bars under the same fill color indicate significant between-treatment differences $(p<0.05)$.

\section{Discussion}

\subsection{Effects of Different Water Treatment Methods on Crop Growth \\ 4.1.1. Effects Related to the Root System}

The root system is the most important functional organ for plants to capture available water and nutrients [46]. Roots play a critical role in the plant-soil ecosystem and significantly influence crop growth and grain yield [26,31]. Root growth and physiological function directly affect crop growth, nutritional status, and yield [36,47]. The $\mathrm{pH}$ and electrical conductivity (EC) increased after magnetic treatment can modify biological activity in plants, and consequently, influence plant growth [48]. Hence, irrigation with magnetized water can promote the growth of the wheat root system, which, in turn, will improve the utilization of water and nutrients [22,49]. Our results showed that magnetization and oxidation could significantly improve winter wheat root vigor $(p<0.05$, Figure 3$)$. Similar patterns were also observed for RLD, RWD, and RSD, with the values of all these root traits significantly higher using GO than in the control samples $(p<0.05)$. This could be attributed to the $\mathrm{pH}$ and EC changes caused by the tested treatments, which could enhance biological activity, and thereby promote root growth [50]. Wang et al. [18] reported that the $\mathrm{pH}$ and EC of the magnetized or oxidized water increased by $3 \%$ and $2 \%$, respectively, and the surface tension was significantly reduced (9.1-13.8\%).

As shown in Figure 4, the substantial increase in the root/shoot ratio of wheat under various treatments was consistent with the results for RLD, RWD and RSD (Table 3). Similarly, it was found that the effect was on the root system rather than on the aboveground 
part of the plants $[23,51]$. It was clearly shown that irrigating winter wheat with magnetized or oxidized water could promote the growth of the wheat root system. Our results also showed that treated brackish water had a positive effect on the root/shoot ratio (Figure 4). It indicates that magnetic treatment or oxidation could efficiently improve the quality of irrigation water in areas plagued by poor water quality. This may be due to the change of the physicochemical properties of brackish water, which could improve the leaching efficiency of soil salt $[18,22]$.

\subsubsection{Effects Related to Chlorophyll Content}

Photosynthesis is the main driving force underlying the distribution of dry matter and organ formation, as well as the basis for the plant production that determines crop yield $[52,53]$. SPAD reflects the total chlorophyll content in the leaves, represents the growth of crop leaves and canopy, and is strongly correlated with photosynthesis [54,55]. As shown in Figure 5, SPAD of wheat leaves could be improved by cultivating winter wheat with magnetized and/or oxidized water. Wang et al. [22]—who also irrigated crops with treated water-also reported that irrigation with treated water increased the chlorophyll content in crop leaves, potentially affecting the conversion of carbohydrates in plants and regulating the synthesis and distribution of photo assimilates. A case study by ECO1ST in the United States found that irrigation with oxidized water can decrease the salinity of irrigation water, which is key to mitigating the possible disadvantages of irrigating crops with brackish water and enhancing the uptake of water stored in the soil $[21,56]$.

\subsection{Links between Root Traits and WUE Improvement}

High yields and WUE in winter wheat require that the root system have a certain absorptive capacity [36]. As such, winter wheat cultivation systems characterized by high yield and low water consumption must promote root growth and maximize the functioning of the wheat root system [57]. Water conditions can significantly influence root growth at the stages of rapid wheat growth, such as jointing and filling, and will subsequently influence grain yields [58,59]. Oxidation and magnetization improved the RLD, RWD and RSD of winter wheat (Table 3). The presented field study results showed that treated water irrigation improved the water use efficiency and grain yield of wheat, and this finding may be related to the utilization of soil water by the root system (Figure 7). This is supported by many comprehensive results $[1,21,28,33]$.

The soil water content of the 60-300 cm soil layers was decreased by both oxidation and magnetization, particularly in the late stages of jointing to maturity (Figure 6). This result, considered together with Figure 3 and Table 3, suggests that the root vigor, along with other root traits, were significantly improved by the $G O$ and $G(O+M)$ treatments. Hence, the grain yields and WUE of the field experiments were improved by irrigation with water that had been magnetized and/or oxidized, treatments that are theorized to promote root growth. The beneficial effects of the magnetic and/or oxidation treatment of irrigation water on soil water absorption could be explained by the lower surface tension and viscosity of the treated water than that of pure groundwater, which would increase water permeability and mobility [60,61]. According to Surendran et al. [20], providing crops with magnetized water can accelerate the activation of enzymes and hormones during the growth process, which may improve the mobilization and transportation of nutrients [48].

\subsection{Implications}

The results showed that irrigation with magnetized and/or oxidized water can improve water utilization in winter wheat relative to plants that have received pure groundwater (Figure 6). Previous studies of the physical and chemical properties suggest that magnetized and oxidized water is less viscous - and thus, more mobile-than pure groundwater, which would improve the permeability of water in the soil [16,22,50]. In other words, the cultivated winter wheat needs to expend less energy to absorb enough water to meet metabolic needs. As mentioned earlier, the benefits of irrigating crops with magnetized 
water are mainly due to a reduction in the surface tension and viscosity coefficient of the treated water [62-64]. In our study, plants which had been treated with magnetized water or oxidized water showed significantly higher germination proportions (Figure 2). Wang et al. [22] summed up the results of previous studies and got a similar conclusion, i.e., beneficial effects of treated irrigation water had been discovered for emergence rate and growing, and many irrigation experiments on corn, wheat and other crops had demonstrated positive biological effects. In addition, root vigor increased following the hydroponic systems including magnetized and/or oxidized water, while the chlorophyll content in the leaves of plants exposed to the oxidized or magnetized water was higher than in the leaves of control plants (Figures 3 and 5). Both of these results suggest that irrigating winter wheat with magnetized and/or oxidized water can promote crop growth and grain formation [51]. Irrigation with magnetized and/or oxidized water could stimulate the activation of enzymes and hormones during crop growth to drive the expression of genes involved in chlorophyll biosynthesis, which would result in the effective mobilization and transportation of water and nutrients. In line with this theory, we have presented evidence that irrigation with magnetized and/or oxidized water improves the absorption of nutrients and water by the winter wheat root system, thus encouraging crop growth and yield.

\section{Conclusions}

The presented results demonstrate that irrigating winter wheat with activated water strongly improved root growth, grain yield and WUE when compared with the results from irrigation with pure groundwater. Irrigation with oxidized water, along with water that was first oxidized and then magnetically treated, showed the most promising results. Under identical irrigation amounts, plots irrigated with oxidized (along with oxidized and subsequently magnetized) water demonstrated higher grain yields and WUE than control (pure groundwater) plots. Furthermore, root vigor, RLD, RWD and RSD all significantly positively increased in plants receiving magnetized and/or oxidized water. The performed experiments revealed that cultivation with magnetized and/or oxidized water promotes the growth of the root system, increases the root/shoot ratio, and significantly increases the chlorophyll content of leaves. In addition, the magnetic and/or oxidation treatment of brackish water improved the root vigor of winter wheat, which could be expected to positively impact crop production. Therefore, irrigation with activated water affects the physiological characteristics of winter wheat by promoting root growth, which translates to better grain yields and the effective utilization of water. The presented evidence could be pivotal to developing approaches for improving grain yields and WUE in the winter wheat production of northwest China.

Author Contributions: Formal analysis, G.Z.; Funding acquisition, Y.M.; Investigation, G.Z., Y.W. and Y.L.; Methodology, G.Z. and B.Z.; Writing-original draft, G.Z.; Writing-review and editing, Y.M. and L.W. All authors have read and agreed to the published version of the manuscript.

Funding: This research was funded by the National Natural Science Foundation of China (41830754).

Data Availability Statement: Data sharing not applicable.

Acknowledgments: The authors are grateful for the support of the staff of the Caoxinzhuang experimental farm of Northwest A\&F University.

Conflicts of Interest: The authors declare there is no conflict of interest.

\section{References}

1. Guan, D.H.; Zhang, Y.S.; Mahdi, M.A.; Wang, Q.Y.; Zhang, M.C.; Li, Z.H. Tillage practices effect on root distribution and water use efficiency of winter wheat under rainfed condition in the North China Plain. Soil Tillage Res. 2015, 146, 286-295. [CrossRef]

2. Islam, M.R.; Eneji, A.E.; Ren, C.Z.; Hu, Y.G.; Chen, G.; Xue, X.Z. Oat-based cropping system for sustainable agricultural development in arid regions of northern China. J. Agric. Biotechnol. Ecol. 2010, 3, 1-8.

3. Varga, B.; Vida, G.; Varga-László, E.; Bencze, S.; Veisz, O. Effect of simulating drought in various phenophases on the water use efficiency of winter wheat. J. Agron. Crop Sci. 2015, 201, 1-9. [CrossRef] 
4. Xie, Y.X.; Zhang, H.; Zhu, Y.J.; Zhao, L.; Yang, J.H.; Cha, F.N.; Liu, C.; Wang, C.Y.; Guo, T.C. Grain yield and water use of winter wheat as affected by water and sulfur supply in the North China Plain. J. Integr. Agric. 2017, 16, 614-625. [CrossRef]

5. Xu, X.X.; Zhang, M.; Li, J.P.; Liu, Z.Q.; Zhao, Z.G.; Zhang, Y.H.; Zhou, S.L.; Wang, Z.M. Improving water use efficiency and grain yield of winter wheat by optimizing irrigations in the North China Plain. Field Crops Res. 2018, 221, 219-227. [CrossRef]

6. Ray, D.K.; Ramankutty, N.; Mueller, N.D.; West, P.C.; Foley, J.A. Recent patterns of crop yield growth and stagnation. Nat. Commun. 2012, 3, 812-818. [CrossRef]

7. Xiao, G.J.; Wang, J. Research on progress of rainwater harvesting agriculture on the Loess Plateau of China. Acta Ecol. Sin. 2003, 23, 1003-1011. (In Chinese with English abstract)

8. Bierkens, M.F.P.; Wada, Y. Non-renewable groundwater use and groundwater depletion: A review. Environ. Res. Lett. 2019, 14, 1-43. [CrossRef]

9. Ali, S.; Xu, Y.Y.; Ma, X.C.; Ahmad, I.; Manzoor; Jia, Q.M.; Akmal, M.; Hussain, Z.; Arif, M.; Cai, T.; et al. Deficit irrigation strategies to improve winter wheat productivity and regulating root growth under different planting patterns. Agric. Water Manag. 2019, 219, 1-11. [CrossRef]

10. Currell, M.J.; Han, D.M.; Chen, Z.Y.; Cartwright, I. Sustainability of groundwater usage in northern China: Dependence on palaeowaters and effects on water quality, quantity and ecosystem health. Hydrol. Process. 2012, 26, 4050-4066. [CrossRef]

11. Du, T.S.; Kang, S.Z.; Zhang, J.H.; Davies, W.J. Deficit irrigation and sustainable water-resource strategies in agriculture for China's food security. J. Exp. Bot. 2015, 66, 2253-2269. [CrossRef] [PubMed]

12. Wu, P.T.; Feng, H.; Niu, W.Q.; Zhao, X.N. Research emphasis and reflection of strategy for water saving agriculture in China. Sci. Technol. Rev. 2006, 24, 86-88. (In Chinese with English abstract)

13. Zhao, H.X.; Zhang, P.; Wang, Y.Y.; Ning, T.Y.; Xu, C.L.; Wang, P. Canopy morphological changes and water use efficiency in winter wheat under different irrigation treatments. J. Integr. Agric. 2020, 19, 1105-1116. [CrossRef]

14. Ambashta, R.D.; Sillanpää, M. Water purification using magnetic assistance: A review. J. Hazard. Mater. 2010, 180, 38-49. [CrossRef]

15. Zhu, L.F.; Zhang, J.H.; Yu, S.M.; Hu, Z.H.; Jin, Q.Y. Magnetized water irrigation enhanced rice growth and development, improved yield and quality. Trans. Chin. Soc. Agric. Eng. 2014, 30, 107-114. (In Chinese with English abstract)

16. Esmaeilnezhad, E.; Choi, H.J.; Schaffie, M.; Gholizadeh, M.; Ranjbar, M. Characteristics and applications of magnetized water as a green technology. J. Clean. Prod. 2017, 161, 908-921. [CrossRef]

17. Mostafazadeh, F.B.; Khoshravesh, M.; Mousavi, S.F.; Kiani, A.R. Effects of magnetized water on soil chemical components underneath trickle irrigation. J. Irrig. Drain. Eng. 2012, 138, 1075-1081. [CrossRef]

18. Wang, Q.J.; Zhang, J.H.; Men, Q.; Tan, S.; Zhou, L.W.; Liu, X.Y. Experiment on physical and chemical characteristics of activated brackish water by magnetization or ionization. Trans. Chin. Soc. Agric. Eng. 2016, 32, 60-66. (In Chinese with English abstract)

19. Al-Ogaidi, A.A.M.; Wayayok, A.; Rowshon, M.K.; Abdullah, A.F. The influence of magnetized water on soil water dynamics under drip irrigation systems. Agric. Water Manag. 2017, 180, 70-77. [CrossRef]

20. Surendran, U.; Sandeep, O.; Mammen, G.; Joseph, E.J. A novel technique of magnetic treatment of saline and hard water for irrigation and its impact on cow pea growth and water properties. Int. J. Agric. Environ. Biotechnol. 2013, 6, 85-92.

21. Mu, Y.; Zhao, G.Q.; Zhao, Q.Q.; Liu, H.; Wang, Q.J. Advances in the application of activated water irrigation. J. Agric. Res. Environ. 2019, 36, 403-411. (In Chinese with English abstract)

22. Wang, Q.J.; Sun, Y.; Ning, S.R.; Zhang, J.H.; Zhou, B.B.; Su, L.J.; Shan, Y.Y. Effects of activated irrigation water on soil physicochemical properties and crop growth and analysis of the probable pathway. Adv. Earth Sci. 2019, 34, 660-670. (In Chinese with English abstract)

23. Maffei, M.E. Magnetic field effects on plant growth, development, and evolution. Front. Plant Sci. 2014, 5, 1-15. [CrossRef]

24. Selim, A.H.; Zayed, M.A.H.; Zayed, M.A.T. Magnetic field treated water effects on germination, growth and physio-chemical aspects of some economic plants. Acta Bot. Hung. 2013, 55, 99-116. [CrossRef]

25. Zhang, L.H. Molecular dynamics simulation of mechanism of increasing vegetable yield by irrigated magnetization water. J. Qingdao Univ. (Natural Science Edition) 2005, 18, 58-62. (In Chinese with English abstract)

26. Feng, S.W.; Gu, S.B.; Zhang, H.B.; Wang, D. Root vertical distribution is important to improve water use efficiency and grain yield of wheat. Field Crops Res. 2017, 214, 131-141. [CrossRef]

27. Peng, B.; Liu, X.W.; Dong, X.J.; Xue, Q.W.; Neely, C.B.; Marek, T.; Ibrahim, A.M.H.; Zhang, G.R.; Leskovar, D.I.; Rudd, J.C. Root morphological traits of winter wheat under contrasting environments. J. Agron. Crop Sci. 2019, 205, 571-585. [CrossRef]

28. Lv, G.H.; Song, J.Q.; Bai, W.B.; Wu, Y.F.; Liu, Y.; Kang, Y.H. Effects of different irrigation methods on micro-environments and root distribution in winter wheat fields. J. Integr. Agric. 2015, 14, 1658-1672. [CrossRef]

29. Zhang, X.Y.; Zhang, X.Y.; Liu, X.W.; Shao, L.W.; Sun, H.Y.; Chen, S.Y. Incorporating root distribution factor to evaluate soil water status for winter wheat. Agric. Water Manag. 2015, 153, 32-41. [CrossRef]

30. Hochholdinger, F. Untapping root system architecture for crop improvement. J. Exp. Bot. 2016, 67, 4431-4433. [CrossRef]

31. Wang, C.Y.; Liu, W.X.; Li, Q.X.; Ma, D.Y.; Lu, H.F.; Feng, W.; Xie, Y.X.; Zhu, Y.J.; Guo, T.C. Effects of different irrigation and nitrogen regimes on root growth and its correlation with above-ground plant parts in high-yielding wheat under field conditions. Field Crops Res. 2014, 165, 138-149. [CrossRef]

32. Lynch, J.P. Root phenes for enhanced soil exploration and phosphorus acquisition: Tools for future crops. Plant Physiol. 2011, 156, 1041-1049. [CrossRef] 
33. Zhang, H.; Xue, Y.G.; Wang, Z.Q.; Yang, J.C.; Zhang, J.H. Morphological and physiological traits of roots and their relationships with shoot growth insuper rice. Field Crops Res. 2009, 113, 31-40. [CrossRef]

34. Ding, Y.F.; Liang, Y.C.; Zhu, J.; Zhao, J. Effects of silicon on plant growth, photosynthetic parameters and soluble sugar content in leaves of wheat under drought stress. Plant Nutr. Fertil. Sci. 2007, 13, 471-478. (In Chinese with English abstract)

35. Dai, X.L.; Wang, Y.C.; Dong, X.C.; Qian, T.F.; Yin, L.J.; Dong, S.X.; Chu, J.P.; He, M.R. Delayed sowing can increase lodging resistance while maintaining grain yield and nitrogen use efficiency in winter wheat. Crop J. 2017, 5, 541-552. [CrossRef]

36. Ma, S.C.; Wang, T.C.; Guan, X.K.; Zhang, X. Effect of sowing time and seeding rate on yield components and water use efficiency of winter wheat by regulating the growth redundancy and physiological traits of root and shoot. Field Crops Res. 2018, 221, 166-174. [CrossRef]

37. Zhang, X.; Huang, G.; Bian, X.; Zhao, Q. Effects of root interaction and nitrogen fertilization on the chlorophyll content, root activity, photosynthetic characteristics of intercropped soybean and microbial quantity in the rhizosphere. Plant Soil Environ. 2013, 59, 80-88. [CrossRef]

38. Gregory, P.J. Root growth and activity. In Physiology and Determination of Crop Yield, American Society of Agronomy; Boote, K.J., Bennett, J.M., Sinclair, T.R., Paulsen, G.M., Eds.; American Society of Agronomy: Madison, WI, USA, $1994 ;$ pp. 65-93.

39. Shahzad, A.; Xu, Y.Y.; Irshad, A.; Jia, Q.M.; Ma, X.C.; Hidayat, U.; Mukhtar, A.; Muhammad, A.; Ihsanullah, D.; Ren, X.L.; et al. Tillage and deficit irrigation strategies to improve winter wheat production through regulating root development under simulated rainfall conditions. Agric. Water Manag. 2018, 209, 44-54. [CrossRef]

40. Wu, Y.C.; Zhou, S.L.; Wang, Z.M.; Feng, H.Y.; Lu, L.Q.; Wang, R.Z. Recovery of residual fertilizer-nitrogen by wheat in a winter wheat-summer maize rotation in the North China Plain: A soil column study. Agron. J. 2009, 101, 925-932. [CrossRef]

41. Zhou, S.L.; Wu, Y.C.; Wang, Z.M.; Lu, L.Q.; Wang, R.Z. The nitrate leached below maize root zone is available for deep-rooted wheat in winter wheat-summer maize rotation in the North China Plain. Environ. Pollut. 2008, 152, 723-730. [CrossRef] [PubMed]

42. Ahmed, N.; Zhang, Y.S.; Li, K.; Zhou, Y.Y.; Zhang, M.C.; Li, Z.H. Exogenous application of glycine betaine improved water use efficiency in winter wheat (Triticum aestivum $L$.) via modulating photosynthetic efficiency and antioxidative capacity under conventional and limited irrigation conditions. Crop J. 2019, 7, 635-650. [CrossRef]

43. Xu, C.L.; Tao, H.B.; Tian, B.J.; Gao, Y.B.; Ren, J.H.; Wang, P. Limited-irrigation improves water use efficiency and soil reservoir capacity through regulating root and canopy growth of winter wheat. Field Crops Res. 2016, 196, 268-275. [CrossRef]

44. Qiu, G.Y.; Wang, L.M.; He, X.H.; Zhang, X.Y.; Chen, S.Y.; Chen, J.; Yang, Y.H. Water use efficiency and evapotranspiration of winter wheat and its response to irrigation regime in the North China Plain. Agric. Forest Meteorol. 2008, 148, 1848-1859. [CrossRef]

45. Lin, W.; Liu, W.Z.; Zhou, S.S.; Liu, C.F. Influence of plastic film mulch on maize water use efficiency in the Loess Plateau of China. Agric. Water Manag. 2019, 224, 1-7. [CrossRef]

46. Li, J.P.; Xu, X.X.; Lin, G.; Wang, Y.Q.; Liu, Y.; Zhang, M.; Zhou, J.Y.; Wang, Z.M.; Zhang, Y.H. Micro-irrigation improves grain yield and resource use efficiency by co-locating the roots and N-fertilizer distribution of winter wheat in the North China Plain. Sci. Total Environ. 2018, 643, 367-377. [CrossRef]

47. Wu, Y.; Wang, H.Z.; Yang, X.W.; Meng, Z.J.; He, D.X. Soil water effect on root activity, root weight density, and grain yield in winter wheat. Crop Sci. 2017, 57, 437-443. [CrossRef]

48. Emil, C.; Aleksandra, S. Magnetic water treatment-A review of the latest approaches. Chemosphere 2018, 203, 54-67. [CrossRef]

49. Savostin, P.V. Magnetic growth relations in plants. Planta 1964, 12, 327.

50. Surendran, U.; Sandeep, O.; Joseph, E.J. The impacts of magnetic treatment of irrigation water on plant, water and soil characteristics. Agric. Water Manag. 2016, 178, 21-29. [CrossRef]

51. Sadeghipour, O.; Aghaei, P. Improving the growth of cowpea (Vigna unguiculata L. Walp.) by magnetized water. J. Biodivers. Environ. Sci. 2013, 3, 37-43.

52. Dong, Z.Y.; Zhang, X.D.; Li, J.; Zhang, C.; Wei, T.; Yang, Z.; Cai, T.; Zhang, P.; Ding, R.X.; Jia, Z.K. Photosynthetic characteristics and grain yield of winter wheat (Triticum aestivum $L$.) in response to fertilizer, precipitation, and soil water storage before sowing under the ridge and furrow system: A path analysis. Agric. For. Meteorol. 2019, 272, 12-19. [CrossRef]

53. Wang, C.; She, H.Z.; Liu, X.B.; Hu, D.; Ruan, R.W.; Shao, M.B.; Zhang, L.Y.; Zhou, L.B.; Zhang, G.B.; Wu, D.Q.; et al. Effects of fertilization on leaf photosynthetic characteristics and grain yield in tartary buckwheat Yunqiao. Photosynthetica 2017, 55, 77-84. [CrossRef]

54. Babar, M.A.; Reynolds, M.P.; Ginkel, M.V.; Klatt, A.R.; Raun, W.R.; Stone, M.L. Spectral reflectance to estimate genetic variation for in-season biomass, leaf chlorophyll, and canopy temperature in wheat. Crop Sci. 2006, 46, 1046-1057. [CrossRef]

55. Broge, N.H.; Mortensen, J.V. Deriving green crop area index and canopy chlorophyll density of winter wheat from spectral reflectance data. Remote Sens. Environ. 2002, 81, 45-57. [CrossRef]

56. Wei, K. Research on Soil Water-Salt Distribution and Cotton Growth Characteristics Using De-Electronic Brackish Water Drip Irrigation with Plastic Mulch. Ph.D. Thesis, Xi'an University of Technology, Xi'an, China, 2018. (In Chinese with English abstract)

57. Wang, Z.M.; Wang, P.; Li, X.H.; Li, J.M.; Lu, L.Q. Principle and technology of water-saving, fertilizer-saving, high-yielding and simple cultivation in winter wheat. Rev. China Agric. Sci. Technol. 2006, 8, 38-44. (In Chinese with English abstract)

58. Çakir, R. Effect of water stress at different development stages on vegetative and reproductive growth of corn. Field Crops Res. 2004, 89, 1-16. [CrossRef]

59. Jia, Q.M.; Chen, K.Y.; Chen, Y.Y.; Ali, S.; Manzoor; Sohail, A.; Fahad, S. Mulch covered ridges affect grain yield of maize through regulating root growth and root-bleeding sap under simulated rainfall conditions. Soil Tillage Res. 2018, 175, 101-111. [CrossRef] 
60. Çelik, Ö.; Atak, Ç.; Rzakulieva, A. Stimulation of rapid regeneration by a magnetic field in Paulownia node cultures. J. Cent. Eur. Agric. 2008, 9, 297-304.

61. Yin, Y.A.; Chen, L.; Li, L.H.; Fan, X.Y.; Wang, Y.Q.; Chen, Y.F. Effects of activated water on agronomic characteristics of rice by drip irrigation under mulch film. China Rice 2018, 24, 70-72. (In Chinese with English abstract)

62. Otsuka, I.; Ozeki, S. Does magnetic treatment of water change its properties? J. Phys. Chem. B 2006, 110, 1509-1512. [CrossRef]

63. Zhou, Q.; Ristenpart, W.D.; Stroeve, P. Magnetically induced decrease in droplet contact angle on nanostructured surfaces. Langmuir ACS J. Surf. Coll. 2011, 27, 11747-11751. [CrossRef] [PubMed]

64. Toledo, E.J.L.; Ramalho, T.C.; Magriotis, Z.M. Influence of magnetic field on physical-chemical properties of the liquid water: Insights from experimental and theoretical models. J. Mol. Struct. 2008, 888, 409-415. [CrossRef] 